\title{
Weak response of the microbial food web of a boreal humic lake to hypolimnetic anoxia
}

\author{
Elina Peltomaa ${ }^{1,4, *}$, Priit Zingel $^{2}$, Anne Ojala $^{3}$ \\ ${ }^{1}$ University of Helsinki, Lammi Biological Station, 16900 Lammi, Finland \\ ${ }^{2}$ Estonian University of Life Sciences, Institute of Veterinary Medicine and Animal Sciences, 51014 Tartu, Estonia \\ ${ }^{3}$ University of Helsinki, Department of Environmental Sciences, 15140 Lahti, Finland \\ ${ }^{4}$ Present address: University of Helsinki, Department of Environmental Sciences, 15140 Lahti, Finland
}

\begin{abstract}
As a consequence of climate change, thermal stratification in lakes strengthens and increases the tendency towards hypolimnetic hypoxia or even anoxia. In the boreal zone, numerous lakes already undergo seasonal hypolimnetic anoxia, but its consequences for the microbial food web (MFW) are still largely unknown. However, the abundance as well as vertical distribution of predators, especially ciliates, in the MFW is generally assumed to be controlled by food and oxygen availability. To determine whether oxygen regulates the MFW, we studied the autotrophic picoplankton (APP), larger phytoplankton, bacteria, nanoflagellates (NFs) and ciliates present throughout the growing season in a small, humic and seasonally strongly stratified lake (ValkeaKotinen) with an anoxic hypolimnion. The prey numbers in Lake Valkea-Kotinen were low, whereas the predators were numerous. The abundance of NFs, which was coupled with that of bacteria, was especially high. However, our results indicated no clear response to oxygen conditions, although the abundances of the predators were generally higher in the oxic than in the anoxic water layers. The only ciliate feeding group that showed a clear response was the omnivores, which thrived in the hypoxic hypolimnion in early summer. The APP and bacterial abundances were in general high in the upper hypolimnion near the thermocline, which in Lake Valkea-Kotinen is prone to convective mixing. This diurnal disturbance nurtures the autotrophic and heterotrophic community around the thermocline and may also explain the rather high predator abundance in the MFW of Lake Valkea-Kotinen.
\end{abstract}

KEY WORDS: Autotrophic picoplankton - Bacteria - Heterotrophic nanoflagellates $\cdot$ Ciliates · Thermocline $\cdot$ Convection

Resale or republication not permitted without written consent of the publisher

\section{INTRODUCTION}

Since the introduction of the concept of the 'microbial loop' by Azam et al. (1983), autotrophic picoplankton (APP), heterotrophic picoplankton and protozoans have become increasingly important in aquatic food web studies. Microbial loops, or, more precisely, microbial food webs (MFWs), have been widely studied in marine habitats as well as in lakes of various trophic states and over wide geographical areas (e.g. Arndt 1993, Amblard et al. 1995, Hadas \& Berman 1998, Zingel et al. 2007, Gobler et al. 2008, Peštová et al. 2008). However, MFWs in lakes with strong thermal stratification and resulting hypolimnetic oxygen depletion are still poorly defined (Eby et al. 2005, Bręk-Laitinen et al. 2012). In addition, few studies have described seasonality in the vertical structure of MFWs (Massana et al. 1996, Kalinowska 2004, Bręk-Laitinen et al. 2012, Colombet \& Sime-Ngando 2012, Rasconi \& Sime-Ngando 2012). This is somewhat perturbing since anoxia which, due to eutrophication and climate change, is among the most severe threats that aquatic ecosystems are facing currently — can lead to major regime shifts in food webs. For instance, protozoans, e.g. heterotrophic nanoflagellates (NFs) and ciliates, can re- 
place macrozooplankton as the main grazers (Masson \& Pinel-Alloul 1998)

In the boreal zone, numerous lakes regularly undergo seasonal hypolimnetic hypoxia and finally anoxia. The special characteristic of these usually small lakes is the high concentration of coloured organic matter (OM) deriving from the catchment, and thus MFW studies in these types of lakes typically focus on bacterial utilization of allochthonous carbon and ignore comprehensive description of the trophic structure of MFWs. Usually boreal lakes are dimictic, but as small and sheltered bodies of water they often undergo incomplete spring turnover and thus their hypolimnia remain anoxic after winter (Huotari et al. 2009). Due to rapid light attenuation, phytoplankton production in humic lakes is restricted to the upper few metres (Arvola 1984, Karlsson et al. 2009, Peltomaa \& Ojala 2010). This results in depletion of epilimnetic inorganic nutrients-most often phosphorus-during summer. However, the nutrients are often abundant in the hypolimnia (Arvola 1984). Phytoplankton communities in humic lakes are dominated by flagellated species capable of migrating vertically between the epilimnion and the hypolimnion (Lepistö \& Rosenström 1998). Furthermore, some of the immobile species, including the APP, have some control of their position in the water column through isopycny and thus are located at the boundary layer between light and nutrient depletion (Peltomaa \& Ojala 2012). However, the importance of APP in the MFWs of humic lakes is thus far unclear. In contrast to phytoplankton, heterotrophic prokaryotes, i.e. bacteria, are more evenly distributed throughout the water column, probably due to the availability of OM (Amblard et al. 1995, Tulonen et al. 2000). The high amount of OM sustains the high biomass of heterotrophic bacteria, which further support the growth of microzooplankton and macrozooplankton (Jones 1992, Daniel et al. 2005).

In general, the abundance and vertical distribution of the grazers in MFWs is controlled by food and/or oxygen availability (Guhl et al. 1996). Many studies have reported NF grazing on bacteria-sized particles (Sherr \& Sherr 2002 and references therein), and since bacteria are abundant in humic lakes, NF growth is supposedly not limited by the availability of bacterial food resources. However, not all NFs are bacterivorous, but are herbivorous or omnivorous (Mischke 1994, Šimek et al. 1997, Bręk-Laitinen \& Ojala 2011). Due to their small size, NFs cannot ingest large cells, which restricts their grazing efficiency (Amblard et al. 1995). NFs do not respond to seasonal anoxia (Gobler et al. 2008, Bręk-Laitinen et al. 2012), whereas the abundance and community structure of ciliated protozoa differ considerably in oxic versus anoxic waters (Guhl et al. 1996, Gobler et al. 2008, Bręk-Laitinen et al. 2012). Some ciliates have specialized diets and are thus dependent on the location of their food resources (Amblard et al. 1995, Guhl et al. 1996, Verni \& Gualtieri 1997, Gobler et al. 2008, Bręk-Laitinen et al. 2012).

Since hypolimnetic oxygen depletion divides the water column into 2 separate parts, and since there are few studies of MFWs in humic lakes, we examined the vertical structure of the MFW in a strongly stratified boreal humic lake with an anoxic hypolimnion. In this lake, the anoxia has strengthened as a consequence of climate change (E. Peltomaa et al. unpubl.). We explored the dynamics of potential 'prey' organisms, e.g. APP, larger phytoplankton and bacteria, and 'predators', e.g. NFs and ciliates, in the small (surface area 4 ha) Lake Valkea-Kotinen in southern Finland. Our aim was to determine the relationships between the potential prey and predators and explain the changes observed in their seasonal dynamics. We also compared the roles of NFs and ciliates as grazers of APP and bacteria in the oxic and anoxic parts of the water column. We hypothesize that NFs are coupled with the presence of bacteria and possibly with APP, but ciliates follow both the dynamics of their particular food source and the dividing line of anoxia. We compared our results with (1) those of Bręk-Laitinen et al. (2012) from the clearwater boreal Lake Vesijärvi, which has a hypoxic/anoxic hypolimnion and is situated only $50 \mathrm{~km}$ from our study lake, and (2) the results of Amblard et al. (1995) from the temperate Lake Vassiviere in France. Lake Vassiviere is a humic lake, but in terms of oxygen does not stratify and thus does not suffer from anoxia. Both of these lakes are considerably larger (surface area of Lake Vesijärvi $108 \mathrm{~km}^{2}$ and Lake Vassiviere $10 \mathrm{~km}^{2}$ ) than Lake Valkea-Kotinen, but were chosen for comparison because so far there are no comprehensive studies of the MFWs in boreal humic lakes with hypolimnetic oxygen depletion.

\section{MATERIALS AND METHODS}

\section{Study site}

Lake Valkea-Kotinen $\left(61^{\circ} 14^{\prime} \mathrm{N}, 25^{\circ} 04^{\prime} \mathrm{E}\right)$ is a shallow (mean depth $2.5 \mathrm{~m}$, maximum depth $6.5 \mathrm{~m}$ ) headwater lake with brown water (colour value $160 \mathrm{mg} \mathrm{Pt}$ $\left.\mathrm{l}^{-1}\right)$. The intense water colour and high concentra- 
tions of dissolved organic carbon (DOC; 9.6 to $12.2 \mathrm{~g}$ $\mathrm{m}^{-3}$ ) are due to allochthonous humic substances originating from the surrounding old-growth forest and peatland (Keskitalo et al. 1998). As a result, light penetration is poor and photoautotrophic production is restricted to the uppermost $2 \mathrm{~m}$ of the epilimnion (Peltomaa \& Ojala 2010). Lake Valkea-Kotinen is steeply stratified both thermally and chemically during summer and used to undergo mixing in spring as well as in autumn; currently the spring turnover is usually short and incomplete (Peltomaa \& Ojala 2012), which was also the case in 2003, when the MFW was studied.

\section{Sample collection and laboratory protocols}

The samples were taken during the open-water period 2003 from the deepest point $(6 \mathrm{~m})$ of the lake once a week between 09:00 and 10:00 h (GMT +2), i.e. from the middle of May till the end of November. The chemical data were collected as a part of the International Cooperative Programme on Integrated Monitoring of Air Pollution Effects on Ecosystems monitoring programme (Niinioja et al. 1995). The water temperature and dissolved oxygen concentration were measured at $1 \mathrm{~m}$ intervals from 0 to $6 \mathrm{~m}$ with a portable YSI 55 combined oxygen meter (Yellow Springs Instruments). The concentrations of inorganic and organic nitrogen and phosphorus, i.e. nitrite and nitrate $\left(\mathrm{NO}_{2}+\mathrm{NO}_{3}\right)$, ammonium $\left(\mathrm{NH}_{4}\right)$, total nitrogen $\left(\mathrm{N}_{\text {tot }}\right)$, phosphate $\left(\mathrm{PO}_{4}\right)$ and total phosphorus $\left(\mathrm{P}_{\text {tot }}\right)$, as well as dissolved inorganic carbon (DIC), were determined from the samples taken with a Limnos tube sampler (length $30 \mathrm{~cm}$ ) from 0, 1, 2, 3 and $5 \mathrm{~m}$. The samples for inorganic nutrients were filtered through GF/C filters (Whatman International), stored frozen, and filtered after thawing through $0.45 \mu \mathrm{m}$ MCE-filters (Millipore). The unfiltered samples for $\mathrm{N}_{\text {tot }}$ and $\mathrm{P}_{\text {tot }}$ were also stored frozen before analysis. The nutrient analyses were based on colorimetric assays (D'Elia et al. 1977, Grasshoff 1983, Koroleff 1983) carried out with a Lachat Quikchem 8000 automatic flow injection analysis system (Zellweger Analytics). DIC was determined from acidified samples with an infrared carbon analyser (Uras 3G; Hartmann \& Braun), as described in Salonen (1981). The samples for enumeration of APP and ciliates were taken with the Limnos at $1 \mathrm{~m}$ intervals between 0 and $6 \mathrm{~m}$. Samples for bacteria and heterotrophic NF enumeration were taken simultaneously with APP and ciliates from depths of $0,2,3$ and $5 \mathrm{~m}$. The APP samples were stored in crushed ice and the cells were counted within $4 \mathrm{~h}$, and all the other community samples were preserved with acid Lugol's solution.

The total phytoplankton biomass was estimated as chlorophyll a ( $\mathrm{chl} a$ ). Chl a was used as a proxy for the biomass of nanophytoplankton and microphytoplankton, which in Lake Valkea-Kotinen form on average $80 \%$ of the total chl a (Peltomaa \& Ojala 2010). For these determinations, samples were drawn into black plastic bottles with a $1 \mathrm{~m}$ tube sampler (volume $7 \mathrm{l}$ ) from every metre between 0 and $5 \mathrm{~m}$. From each depth, 400-500 ml of water was filtered through a Whatman GF/C fibreglass filter. The chl a was hot-extracted $\left(+75^{\circ} \mathrm{C}, 5 \mathrm{~min}\right)$ from the filters with $94 \%$ ethanol and the absorption of the extract was measured with a Shimadzu UV-2100 spectrophotometer at 665 and $750 \mathrm{~nm}$ (Keskitalo \& Salonen 1994). The concentration of chl a was calculated using an absorption coefficient of $83.4 \mathrm{l} \mathrm{g}^{-1} \mathrm{~cm}^{-1}$ (Wintermans $\&$ De Mots 1965)

\section{Community composition}

APP, bacteria and NFs were enumerated with epifluorescence microscopy (Olympus IX50; total magnification of $1000 x_{i}$ blue filter set U-MWB: excitation filter 450 to $480 \mathrm{~nm}$, dichroic mirror $500 \mathrm{~nm}$, barrier filter $515 \mathrm{~nm}$ ). The numbers of observed fields of view were adapted to APP, bacteria and NFs to obtain an accuracy of $10 \%$ (Lund et al. 1958). The APP samples were kept in darkness in crushed ice until observed under the microscope within $4 \mathrm{~h}$. For counting, the APP samples (2 to $5 \mathrm{ml}$ ) were filtered onto black polycarbonate membrane filters with a pore size of $0.2 \mu \mathrm{m}$ (Osmonics), and the APP cells were detected from 40 to 50 fields of view, based on $\mathrm{chl} a$ autofluorescence (Peltomaa \& Ojala 2012). The filtration for bacteria (subsamples of 0.5 to $3 \mathrm{ml}$ ) was otherwise similar to that of APP, but the bacteria were stained with acriflavine (Bergström et al. 1986) and at least 30 fields were counted. A video camera and the analySIS 3.0 image analysing program (Soft Imaging System) were used to determine the cell volumes of the bacteria. The NF total numbers (i.e. the pigmented but possibly mixotrophic flagellates were not distinguished from the non-pigmented ones) were determined from subsamples of 5 to $10 \mathrm{ml}$, which were stained and counted as bacteria, using filters with the pore size of $1.0 \mu \mathrm{m}$ (Sanders et al. 1989). The ciliate community composition (subsamples of $50 \mathrm{ml}$ ) was determined with a Nikon DiaphotTMD inverted microscope, using a total magnification of 200 to $1000 \times$ and the Utermöhl settling 
chamber technique (Utermöhl 1958). The entire content of each counting chamber was surveyed. Ciliates were usually identified to genus level consulting several works (Kahl 1930, 1931, 1932, 1935, Foissner \& Berger 1996, Foissner et al. 1999). They were divided into 4 ecological groups (algivorous, bacterivorous, omnivorous and predatory ciliates) using data from several feeding experiments (e.g. Kisand \& Zingel 2000, Agasild et al. 2007, Zingel et al. 2007, Zingel \& Nõges 2008) and consulting corresponding literature (Foissner et al. 1991, 1992, 1994, 1995).

\section{Statistical analyses}

The relationships between the stocks of prey organisms and the abiotic environmental factors as well as grazers/predators were determined with bivariate correlation analysis (Pearson). Differences in abundance between the oxic epilimnion and the anoxic hypolimnion were analysed with one-way ANOVA. The homogeneity of variances was tested with Levene's test and the normality of the experimental data was tested with the Kolmogorov-Smirnov goodnessof-fit test. $\log _{10}$ transformation was used to normalise the distribution of the data before the statistical analyses. The level of significance was set at $\mathrm{p}<0.05$, and the analyses were carried out with SPSS 15.0 for Windows. Canonical correspondence analysis (CCA) was applied to link the ciliate abundance with water temperature, oxygen concentration, abundances of APP, bacteria and NFs, as well as chl a concentration. Since the bacteria and NFs were counted only from depths of $0,2,3$ and $5 \mathrm{~m}$, the values for the missing depths were interpolated linearly for CCA. The randomization tests (Monte Carlo) in CCA were run with 999 permutations. The CCAs were carried out using the Palaeontological Statistics (PAST) program, version 2.12 (Hammer et al. 2001).

\section{RESULTS}

\section{Physical and chemical conditions}

The ice-out in 2003 occurred in late April and the thermal stratification developed shortly afterwards and continued into the summer (Fig. 1A). Hypolimnetic anoxia, developed during winter, was not completely resolved, and thus the lower part of the hypolimnion was already anoxic and the upper part hypoxic at the onset of summer (Fig. 1B). The incomplete spring mixing also prevented nutrient supply from the nutrient-rich bottom to the surface, which led to large differences in the concentrations of $\mathrm{NO}_{2}+\mathrm{NO}_{3}, \mathrm{~N}_{\text {tot }}$ and $\mathrm{P}_{\text {tot }}$ between the epilimnion ( 0 to $2 \mathrm{~m}$ ) and the hypolimnion ( 3 to $6 \mathrm{~m}$ ) (Table 1).
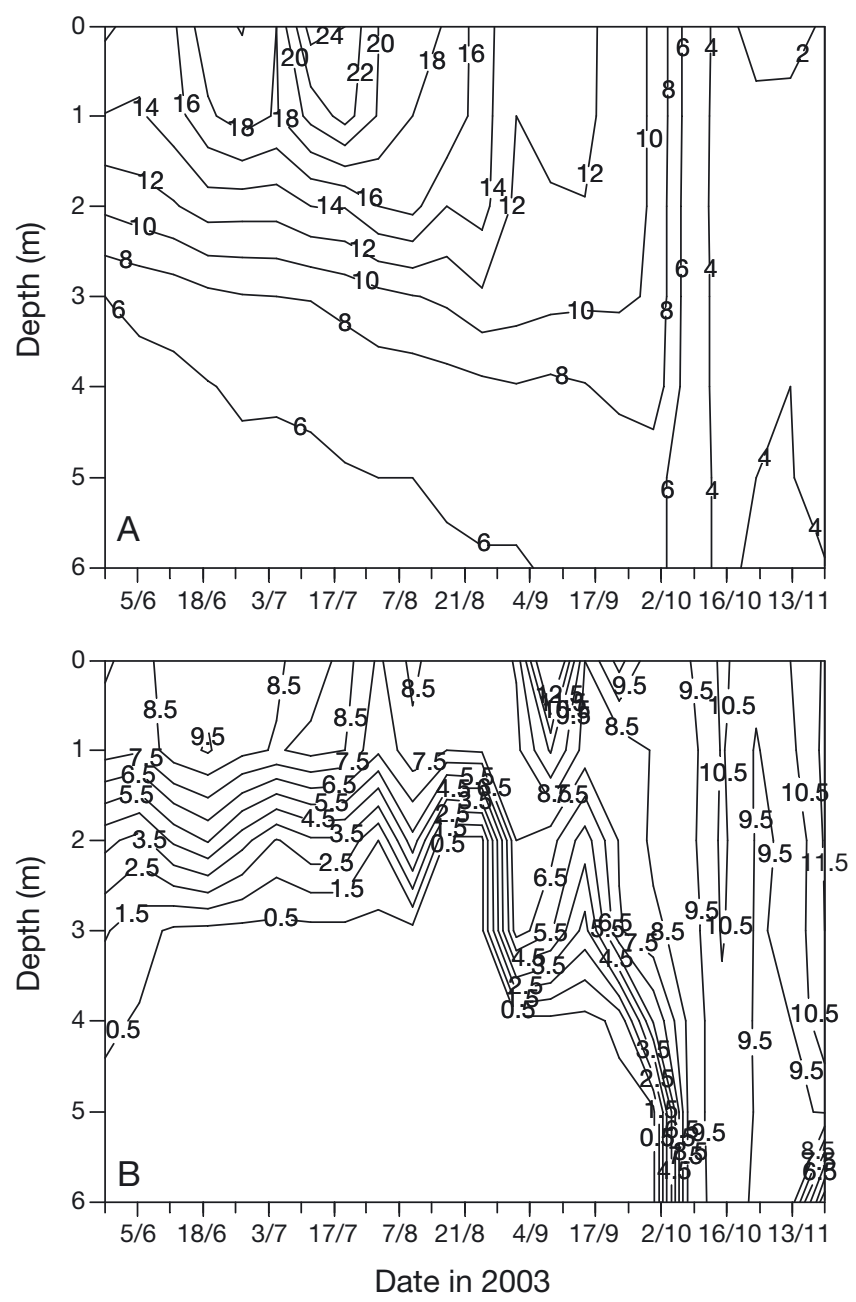

Fig. 1. (A) Temperature $\left({ }^{\circ} \mathrm{C}\right)$ and $(\mathrm{B})$ oxygen $\left(\mathrm{mg} \mathrm{l}^{-1}\right)$ in Lake Valkea-Kotinen during the open-water period in 2003. Dates are given as $\mathrm{d} / \mathrm{mo}$

Table 1. Mean concentrations of nutrients $\left(\mathrm{mg} \mathrm{m}^{-3}\right)$ and dissolved inorganic carbon (DIC; $\mathrm{g} \mathrm{m}^{-3}$ ) during stratification in the epilimnion and the hypolimnion in Lake Valkea-Kotinen in 2003. Standard errors of means are given in parentheses

\begin{tabular}{|lcc|}
\hline & Epilimnion & Hypolimnion \\
\hline $\mathrm{NO}_{2}+\mathrm{NO}_{3}$ & $13.3(0.08)$ & $138.6(0.05)$ \\
$\mathrm{NH}_{4}$ & $11.6(0.53)$ & $11.4(1.83)$ \\
$\mathrm{N}_{\text {tot }}$ & $389(1.2)$ & $590(2.5)$ \\
$\mathrm{PO}_{4}$ & $1.0(0.00)$ & $1.2(0.01)$ \\
$\mathrm{P}_{\text {tot }}$ & $11.9(0.04)$ & $20.0(0.07)$ \\
$\mathrm{N}_{\text {tot }}: \mathrm{P}_{\text {tot }}$ & $33(0.08)$ & $30(0.06)$ \\
$\mathrm{DIC}$ & $1.1(0.02)$ & $6.2(0.03)$ \\
\hline
\end{tabular}


The $\mathrm{NH}_{4}$ and $\mathrm{PO}_{4}$ concentrations were quite constant throughout the water column. However, the amount of inorganic phosphorus was very low and phosphorus was probably the limiting inorganic nutrient in Lake Valkea-Kotinen (Table 1). In addition, the $\mathrm{N}_{\text {tot }}: P_{\text {tot }}$ mass ratios of $33(\mathrm{SE}=0.08)$ and 30 ( $\mathrm{SE}=0.06)$ indicated phosphorus depletion in the epilimnion and hypolimnion, respectively (Table 1). In contrast to spring, the autumn turnover was complete: the breakdown in stratification began in mid-September and the entire water column was mixed in mid-October (Fig. 1). The lake froze over in late November.

\section{Prey organisms}

The prey components studied showed wide temporal as well as seasonal variation in abundance. The solitary APP consisted of eukaryotic Choricystis-type cells, and there was some APP present throughout the sampling period (average $6.4 \times 10^{3} \mathrm{cells} \mathrm{ml}^{-1}$, range 1.0 to $25 \times 10^{3}$ cells ml $^{-1}$; Fig. $2 \mathrm{~A}$ ). The first APP maximum occurred in June throughout the epilimnion $\left(23 \times 10^{3}\right.$ cells $\left.\mathrm{ml}^{-1}\right)$, but the second peak in August $\left(20 \times 10^{3}\right.$ cells ml $\left.^{-1}\right)$ was observed at approximately $3 \mathrm{~m}$, i.e. in the upper hypolimnion near the thermocline (Fig. 2A). The average concentration of
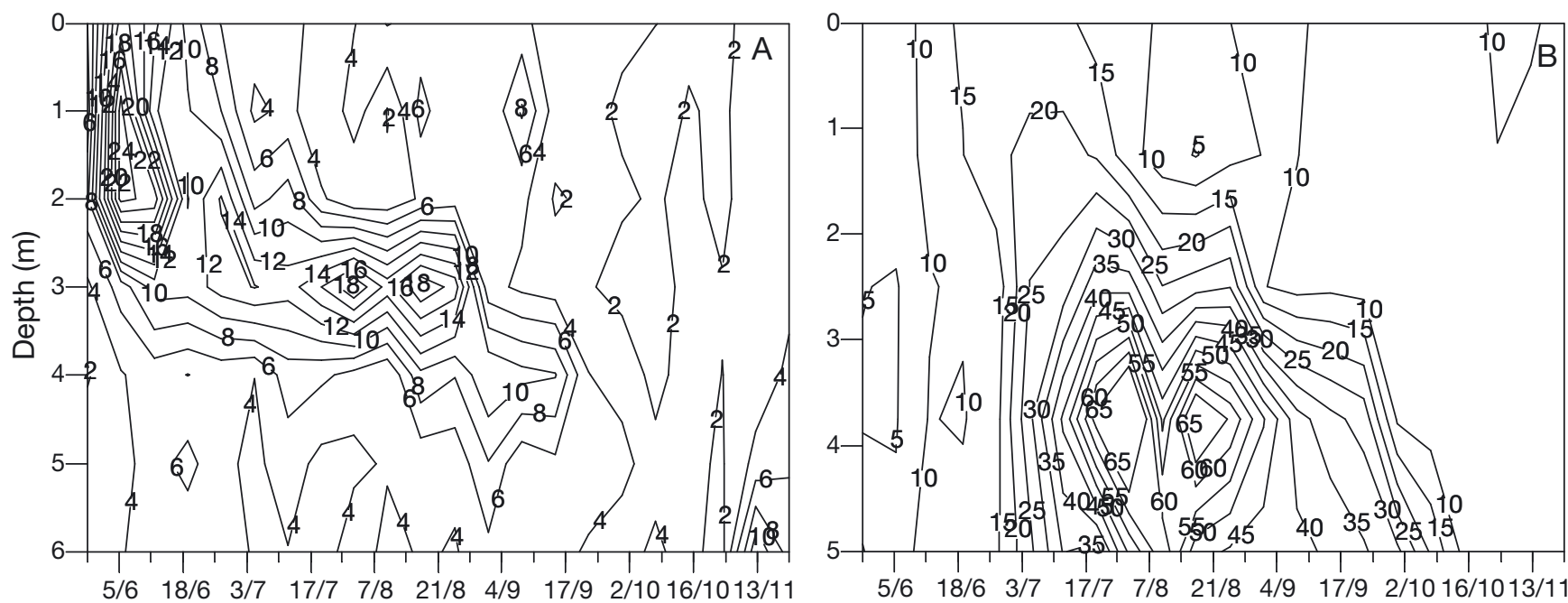

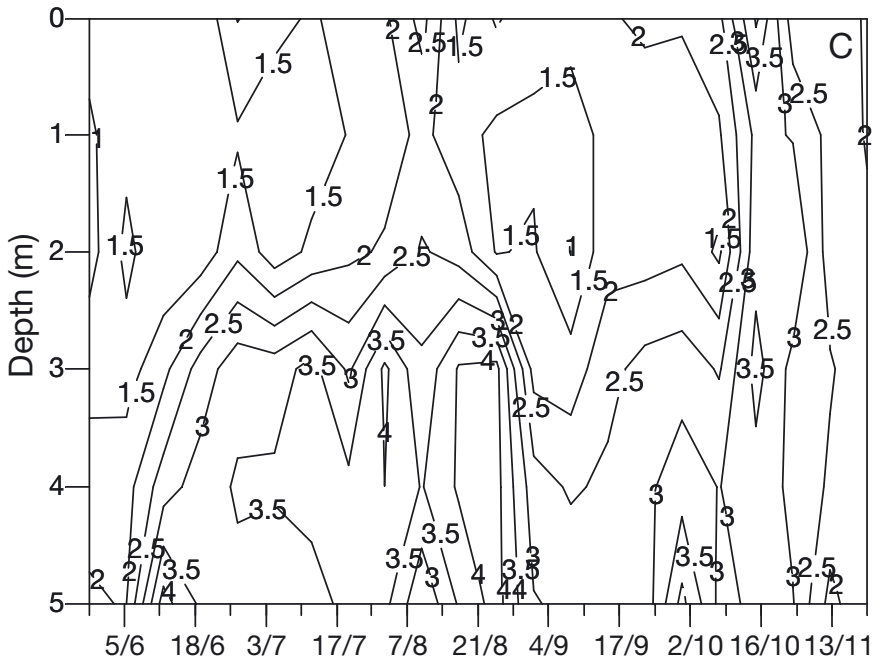

Date in 2003

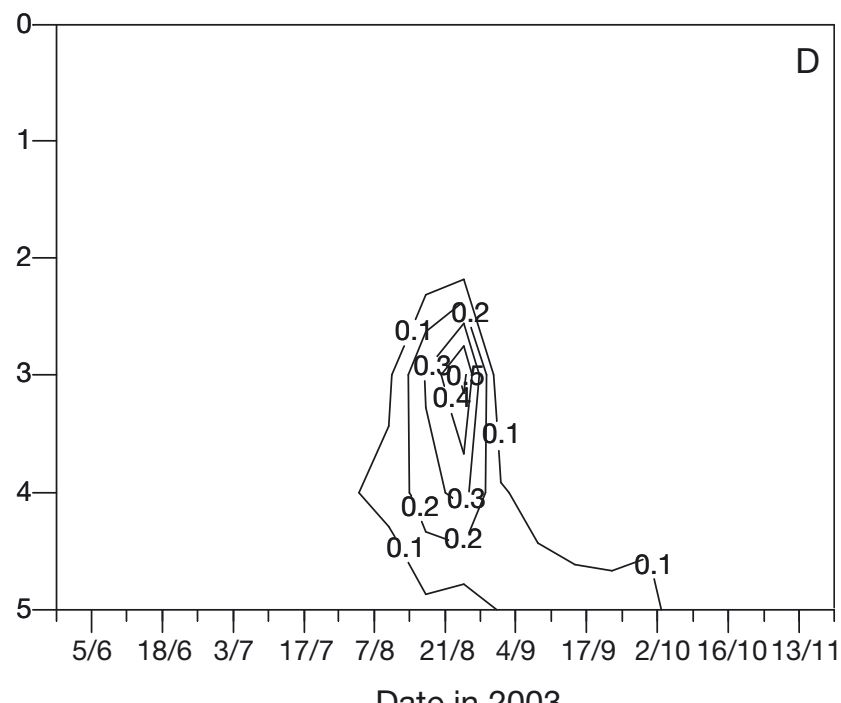

Fig. 2. Vertical distribution of (A) autotrophic picoplankton $\left(10^{3}\right.$ cells ml-1 $)$, (B) chlorophyll a $\left(\mathrm{mg} \mathrm{m}^{-3}\right)$, (C) small bacteria $\left(10^{6}\right.$ cells $\left.\mathrm{ml}^{-1}\right)$ and (D) large bacteria $\left(10^{6} \mathrm{cells} \mathrm{ml}^{-1}\right)$ in Lake Valkea-Kotinen during the open-water period in 2003 . Note different scales on $y$-axes. Dates are given as $\mathrm{d} / \mathrm{mo}$ 
chl a was $19 \mathrm{mg} \mathrm{m}^{-3}$ (range 4.4 to $83 \mathrm{mg} \mathrm{chl} \mathrm{a} \mathrm{m}^{-3}$ ), with only one clear seasonal maximum in JulyAugust, which (instead of in the epilimnion) was recorded in the hypolimnion (Fig. 2B). The maximum mainly comprised the raphidophyte Gonyostomum semen. Besides G. semen, most of the phytoplankton biomass in Lake Valkea-Kotinen consisted of dinoflagellates (Peridinium and Gymnodinium) and flagellated chrysophytes (Pedinella and Syncrypta) and cryptophytes (Cryptomonas) (data not shown). APP as well as the larger phytoplankton, measured as chl a, correlated positively with the $\mathrm{PO}_{4}$ concentrations, which is consistent with the assumption of the lake being phosphorus-limited. There was a negative correlation between $\mathrm{NO}_{2}+\mathrm{NO}_{3}, \mathrm{NH}_{4}$ and $\mathrm{N}_{\text {tot }}$ concentrations and APP, as well as between $\mathrm{NO}_{2}+\mathrm{NO}_{3}$ and $\mathrm{NH}_{4}$ concentrations and chl a (Table 2).

Although bacteria were naturally present continually throughout the water column (average $2.4 \times 10^{6}$ cells $\mathrm{ml}^{-1}$, range 0.81 to $4.2 \times 10^{6}$ cells ml $^{-1}$; Fig. $2 \mathrm{C}$ ), during thermal stratification their numbers were up to 2 times higher in the anoxic hypolimnion than in the epilimnion (ANOVA, $\mathrm{p}<0.001, \mathrm{n}=88$ ). There was a group of prokaryotes with a cell volume 50 times larger than most of the cells in the group of bacteria, which in summer during anoxia resided in the hypolimnion (ANOVA, $\mathrm{p}<0.001, \mathrm{n}=88$; Fig. 2D). These cells were treated separately in the statistical tests, i.e. the tests were run for the 'small' (mean $\pm \mathrm{SE}$ volume $0.02 \pm 0.001 \mu^{3}$ ) and 'large' (mean \pm SE vol-

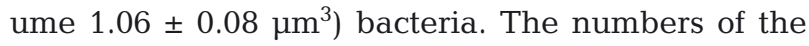
small bacteria increased slowly during summer and attained a modest maximum in July-August at the time of the hypolimnetic chl a maximum ( $r=0.752$, $\mathrm{p}<0.01$; Table 3$)$. The small bacteria attained their highest numbers, $3.5 \times 10^{6}$ cells ml $^{-1}$, in October after the autumn turnover, when they were also evenly distributed throughout the water column (Fig. 2C). The large bacteria attained a maximum of $0.53 \times 10^{6}$

Table 2. Pearson correlation coefficients $(r)$ for environmental parameters and autotrophic picoplankton (APP), chlorophyll $a$ (chl a) and small and large bacteria in Lake Valkea-Kotinen during the open-water period in 2003. ${ }^{*} \mathrm{p}<0.05 ;{ }^{* *} \mathrm{p}<0.01 ;{ }^{* * *} \mathrm{p}<0.001 ;$ ns: not statistically significant

\begin{tabular}{|lcccccccc|}
\hline & APP & $\mathrm{n}$ & Chl a & $\mathrm{n}$ & $\begin{array}{c}\text { Small } \\
\text { bacteria }\end{array}$ & $\mathrm{n}$ & $\begin{array}{c}\text { Large } \\
\text { bacteria }\end{array}$ & $\mathrm{n}$ \\
\hline $\mathrm{NO}_{2}+\mathrm{NO}_{3}$ & $-0.207^{*}$ & 110 & $-0.270^{*}$ & 88 & $\mathrm{~ns}$ & 88 & $-0.240^{*}$ & 88 \\
$\mathrm{NH}_{4}$ & $-0.202^{*}$ & 110 & $-0.305^{* *}$ & 88 & $0.431^{* * *}$ & 88 & $0.275^{*}$ & 88 \\
$\mathrm{~N}_{\text {tot }}$ & $-0.239^{*}$ & 109 & $\mathrm{~ns}$ & 88 & $0.528^{* * *}$ & 87 & $0.345^{* *}$ & 87 \\
$\mathrm{PO}_{4}$ & $0.241^{*}$ & 110 & $0.334^{* *}$ & 88 & $\mathrm{~ns}$ & 87 & $\mathrm{~ns}$ & 87 \\
$\mathrm{P}_{\text {tot }}$ & $\mathrm{ns}$ & 110 & $\mathrm{~ns}$ & 88 & $0.577^{* * *}$ & 87 & $0.408^{* * *}$ & 87 \\
$\mathrm{DIC}$ & $\mathrm{ns}$ & 110 & $0.606^{* * *}$ & 110 & $0.571^{* * *}$ & 88 & $0.557^{* * *}$ & 88 \\
\hline
\end{tabular}

cells $\mathrm{ml}^{-1}$ in the hypolimnion in August simultaneously with the smaller bacteria, but even then they contributed no more than $11 \%$ of the total number of bacteria (Fig. 2D).

The numbers of small bacteria correlated positively with the concentrations of $\mathrm{N}_{\text {tot }}$ and $\mathrm{P}_{\text {tot, }}$ as well as with $\mathrm{NH}_{4}$ and DIC (Table 2). The small bacteria and the APP correlated negatively in the oxic epilimnion $(r=-0.493, \mathrm{p}<0.001)$, but the correlation was positive in the anoxic hypolimnion $(r=0.359$, p $<0.05$; Table 3). Similarly, the large bacteria correlated positively with the concentrations of $\mathrm{N}_{\text {tot }}$ and $\mathrm{P}_{\text {tot }}$, as well as $\mathrm{NH}_{4}$ and DIC (Table 2). There was also a positive correlation between the large prokaryotes and APP, chl $a$ and small bacteria $(r=0.426, \mathrm{p}<0.05, r=0.565$, $\mathrm{p}<0.05$ and $r=0.495, \mathrm{p}<0.01$, respectively; Table 3 ).

\section{Grazers and predators}

The NFs were present throughout the water column during the summer (average $6.6 \times 10^{3} \mathrm{cells} \mathrm{ml}^{-1}$, range 1.0 to $23 \times 10^{3}$ cells $\mathrm{ml}^{-1}$ ), but were most numerous in the oxic water layers (ANOVA, $\mathrm{p}<0.01, \mathrm{n}=88$; Fig. 3A). The NFs showed 3 clear maxima, 2 of which occurred in the epilimnion: the first with $12 \times 10^{3}$ cells $\mathrm{ml}^{-1}$ in May-June and the second with $23 \times 10^{3}$ cells $\mathrm{ml}^{-1}$ in August. The third maximum of $12 \times 10^{3}$ cells $\mathrm{ml}^{-1}$ was visible throughout the water column during the autumn turnover. We found no correlation between the NFs and APP, but the NFs correlated negatively with the small bacteria in the epilimnion as well as in the hypolimnion $(r=-0.265, \mathrm{p}<0.05$ and $r=-0.576, \mathrm{p}<0.01$, respectively; Table 3 ); thus, it is possible that the NFs were grazing on bacteria.

In all, 27 ciliate taxa were identified in Lake Valkea-Kotinen (Table 4). Five of the taxa were found only in the epilimnion, whereas there were only 2 taxa that were present solely in the anoxic hypolimnion. However, all of these 7 taxa were few in numbers (Table 4). The mean ciliate abundance was 7.1 cells $\mathrm{ml}^{-1}$ (range 0.58 to 36 cells $\mathrm{ml}^{-1}$ ), but during stratification the ciliates were on average 1.5 times more abundant in the epilimnion than in the hypolimnion. The dynamics of the various ciliate feeding groups varied remarkably. The algivorous ciliates, capable of feeding on APP, were the most abundant group $(51 \%$ of the total ciliate number) and were present in the epilimnion throughout the 
Table 3. Pearson correlation coefficients $(r)$ for autotrophic picoplankton (APP), chlorophyll a (chl a), small bacteria, large bacteria, nanoflagellates (NF), and bacterivorous, algivorous, omnivorous and predatory ciliates in Lake Valkea-Kotinen during the open-water period in 2003. Large bacteria were not detected (nd) in the epilimnion, and thus the correlations were not calculated $(-) .{ }^{*} \mathrm{p}<0.05{ }^{* *} \mathrm{p}<0.01{ }^{* * *} \mathrm{p}<0.001 ;$ ns: not statistically significant

\begin{tabular}{|c|c|c|c|c|c|c|c|c|}
\hline & \multirow{2}{*}{ APP } & \multirow{2}{*}{ Chl a } & \multicolumn{2}{|c|}{ - Bacteria } & \multirow{2}{*}{ NF } & \multicolumn{3}{|c|}{ _ Ciliates } \\
\hline & & & Small & Large & & Bacterivorous & Algivorous & Omnivorous \\
\hline \multicolumn{9}{|l|}{ Epilimnion } \\
\hline Chl a & ns & & & & & & & \\
\hline $\mathrm{n}$ & 79 & & & & & & & \\
\hline Small bacteria & $-0.493^{* * *}$ & ns & & & & & & \\
\hline $\mathrm{n}$ & 56 & 51 & & & & & & \\
\hline Large bacteria & - & - & & & & & & \\
\hline $\mathrm{n}$ & nd & nd & nd & & & & & \\
\hline NF & ns & $\mathrm{ns}$ & $-0.265^{*}$ & - & & & & \\
\hline $\mathrm{n}$ & 56 & 51 & 56 & nd & & & & \\
\hline Bacterivorous ciliates & ns & ns & ns & - & ns & & & \\
\hline $\mathrm{n}$ & 89 & 79 & 56 & nd & 56 & & & \\
\hline Algivorous ciliates & $0.401^{* * *}$ & ns & $-0.309^{*}$ & - & ns & ns & & \\
\hline $\mathrm{n}$ & 89 & 79 & 56 & nd & 56 & 89 & & \\
\hline Omnivorous ciliates & $0.240^{*}$ & ns & ns & - & $\mathrm{ns}$ & ns & ns & \\
\hline $\mathrm{n}$ & 89 & 79 & 56 & nd & 56 & 89 & 89 & \\
\hline Predatory ciliates & ns & ns & $0.588^{* * *}$ & - & $-0.514^{* * *}$ & $0.583^{* * *}$ & ns & ns \\
\hline $\mathrm{n}$ & 89 & 79 & 56 & nd & 56 & 89 & 89 & 89 \\
\hline \multicolumn{9}{|l|}{ Hypolimnion } \\
\hline Chl a & $0.616^{* * *}$ & & & & & & & \\
\hline $\mathrm{n}$ & 31 & & & & & & & \\
\hline Small bacteria & $0.359^{*}$ & $0.752^{* *}$ & & & & & & \\
\hline $\mathrm{n}$ & 32 & 15 & & & & & & \\
\hline Large bacteria & $0.426^{*}$ & $0.565^{*}$ & $0.495^{*}$ & & & & & \\
\hline $\mathrm{n}$ & 32 & 15 & 32 & & & & & \\
\hline NF & ns & ns & $-0.576^{* *}$ & ns & & & & \\
\hline $\mathrm{n}$ & 32 & 15 & 32 & 32 & & & & \\
\hline Bacterivorous ciliates & ns & ns & ns & ns & $-0.477^{* *}$ & & & \\
\hline $\mathrm{n}$ & 65 & 31 & 32 & 32 & 32 & & & \\
\hline Algivorous ciliates & ns & $-0.583^{* *}$ & $-0.369^{*}$ & ns & ns & ns & & \\
\hline $\mathrm{n}$ & 65 & 31 & 32 & 32 & 32 & 65 & & \\
\hline Omnivorous ciliates & $-0.454^{*}$ & $\mathrm{~ns}$ & ns & ns & $\mathrm{ns}$ & $\mathrm{ns}$ & $0.716^{* * *}$ & \\
\hline $\mathrm{n}$ & 65 & 31 & 32 & 32 & 32 & 65 & 65 & \\
\hline Predatory ciliates & $\mathrm{ns}$ & $-0.365^{*}$ & ns & ns & $\mathrm{ns}$ & $\mathrm{ns}$ & ns & ns \\
\hline $\mathrm{n}$ & 65 & 31 & 32 & 32 & 32 & 65 & 65 & 65 \\
\hline
\end{tabular}

summer (average in epilimnion 5.5 cells $\mathrm{ml}^{-1}$, range 0.6 to 34 cells $\mathrm{ml}^{-1}$ ). Their numbers were highest in June during the epilimnetic APP maximum, and they correlated positively with the APP in the epilimnion ( $r=0.401, \mathrm{p}<0.001$; Table 3, Fig. 3B). The most abundant algivorous species in the epilimnion were the prostomatid Urotricha sp. and the oligotrich Rimostrombidium sp. in the size class 20 to $40 \mu \mathrm{m}$; in the hypolimnion, Urotricha sp. and another unidentified prostomatid were the most abundant algivorous species (Table 4). In August during the strongest stratification, the algivorous ciliates were less abundant in the anoxic hypolimnion (ANOVA, p < $0.001, \mathrm{n}=154)$. Since the anoxic waters were almost void of algivores, there was a negative correlation between the algivorous ciliates and chl $a$ in the hypolimnion $(r=-0.583, \mathrm{p}<0.01$; Table 3$)$. There was also a negative correlation between the ciliates classified as algivorous and small bacteria $(r=-0.319, \mathrm{p}<$ 0.05 and $r=-0.369, \mathrm{p}<0.05$ in the epilimnion and hypolimnion, respectively; Table 3 ).

The bacterivorous ciliates were the second largest group, contributing $42 \%$ of the total ciliate numbers. They were present throughout the water column almost continually (average 3.0 cells ml $^{-1}$, range 0.1 to 22 cells $\mathrm{ml}^{-1}$ ), but showed a clear maximum after autumn mixing in November (12 cells ml ${ }^{-1}$; Fig. 3C). The bacterivorous ciliates were low in numbers in the epilimnion during the NF maximum (Fig. 3), and in the hypolimnion their numbers correlated negatively with the NFs $(r=-0.477, \mathrm{p}<0.01$; Table 3$)$, which may have indicated food competition between 

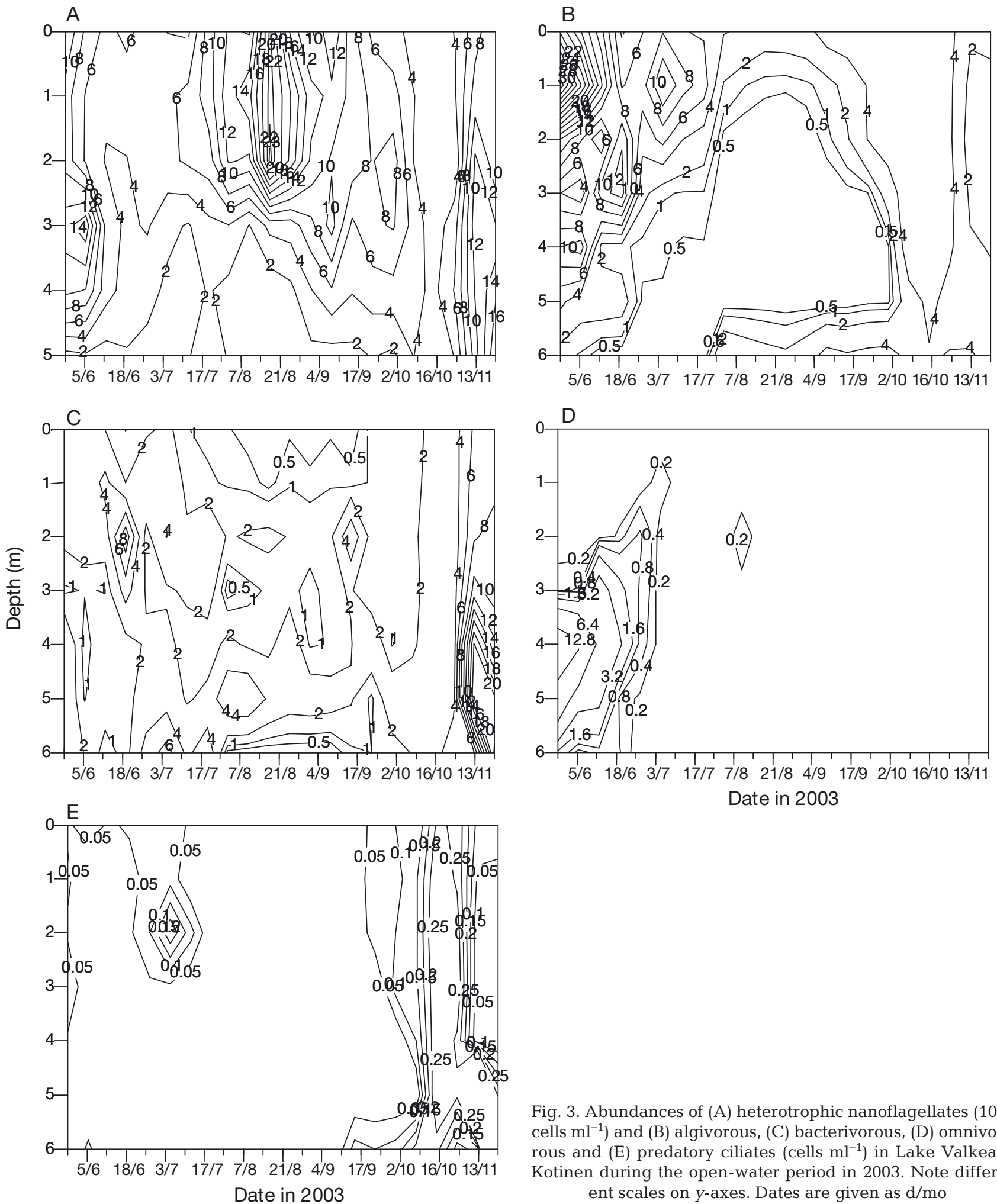

Date in 2003

Fig. 3. Abundances of (A) heterotrophic nanoflagellates $\left(10^{3}\right.$ cells $\mathrm{ml}^{-1}$ ) and (B) algivorous, (C) bacterivorous, (D) omnivorous and (E) predatory ciliates (cells $\mathrm{ml}^{-1}$ ) in Lake ValkeaKotinen during the open-water period in 2003. Note different scales on $y$-axes. Dates are given as $\mathrm{d} / \mathrm{mo}$

these 2 groups. However, no correlation between the bacterivorous ciliates and small bacteria was found. The most abundant bacterivores in the epilimnion were the oligotrich Rimostrombidium sp. in the size class $<20 \mu \mathrm{m}$ and the scuticociliate Cyclidium sp. In the hypolimnion, the most numerous taxa were Cyclidium sp. and an unidentified scuticociliate (Table 4). 
Table 4. Ciliate taxa observed and their feeding preference (A: algivorous; B: bacterivorous; O: omnivorous: P: predatory) and abundance (cells $\mathrm{ml}^{-1}$ ) in the epilimnion and the hypolimnion. nd: not detected

\begin{tabular}{|c|c|c|c|c|}
\hline \multirow{2}{*}{ Taxon } & \multirow{2}{*}{ Taxonomy } & \multirow{2}{*}{$\begin{array}{c}\text { Feeding } \\
\text { preference }\end{array}$} & \multicolumn{2}{|c|}{ Abundance (cells ml-1) } \\
\hline & & & Epilimnion & Hypolimnion \\
\hline Limnostrombidium sp. & Oligotrichia & $\mathrm{A}$ & 0.331 & 0.061 \\
\hline Pelagostrombidium sp. & Oligotrichia & A & 0.118 & 0.031 \\
\hline Rimostrombidium sp. $<20 \mu \mathrm{m}$ & Oligotrichia & $\mathrm{B}$ & 1.462 & 0.185 \\
\hline Rimostrombidium sp. $>40 \mu \mathrm{m}$ & Oligotrichia & $\mathrm{A}$ & 0.197 & 0.074 \\
\hline Rimostrombidium sp. 20-40 $\mu \mathrm{m}$ & Oligotrichia & $\mathrm{A}$ & 0.994 & 0.127 \\
\hline Halteria sp. & Stichotrichia & $\mathrm{B}$ & 0.160 & 0.020 \\
\hline Codonella cratera & Polyhymenophora & $\mathrm{A}$ & 0.001 & nd \\
\hline Askenasia volvox & Haptoria & $\mathrm{A}$ & 0.240 & 0.041 \\
\hline Didinium sp. & Haptoria & $\mathrm{P}$ & 0.001 & nd \\
\hline Dileptus sp. & Haptoria & $\mathrm{P}$ & 0.038 & 0.006 \\
\hline Mesodinium sp. & Haptoria & $\mathrm{O}$ & 0.001 & nd \\
\hline Gymnostomatida sp. & Gymnostomatida & $\mathrm{P}$ & 0.002 & 0.002 \\
\hline Cyclidium sp. & Scuticociliatida & B & 1.025 & 0.938 \\
\hline Scuticociliatida sp. & Scuticociliatida & $\mathrm{B}$ & 0.061 & 0.915 \\
\hline Uronema sp. & Scuticociliatida & $\mathrm{B}$ & 0.037 & 0.003 \\
\hline Lembadion magnum & Oligohymenophora & $\mathrm{O}$ & 0.002 & 0.084 \\
\hline Hymenostomata sp. & Hymenostomata & $\mathrm{O}$ & 0.006 & 0.802 \\
\hline Balanion planktonicum & Prostomatida & $\mathrm{A}$ & 0.303 & 0.039 \\
\hline Coleps sp. & Prostomatida & $\mathrm{O}$ & 0.007 & 0.044 \\
\hline Prostomatida sp. & Prostomatida & $\mathrm{A}$ & 0.023 & 0.463 \\
\hline Urotricha sp. & Prostomatida & $\mathrm{A}$ & 2.904 & 0.939 \\
\hline Vorticella sp. & Peritrichia & $\mathrm{B}$ & 0.020 & nd \\
\hline Hypotrichida sp. & Hypotrichida & $\mathrm{O}$ & 0.014 & 0.138 \\
\hline Stentor sp. & Heterotrichida & $\mathrm{O}$ & nd & 0.029 \\
\hline Caenomorpha sp. & Amphorida & $\mathrm{B}$ & nd & 0.005 \\
\hline Lagynophora sp. & Lagynophora & $\mathrm{P}$ & 0.004 & 0.002 \\
\hline Loxophyllum sp. & Pleurostomatida & $\mathrm{P}$ & 0.002 & nd \\
\hline
\end{tabular}

The omnivores made up $6.7 \%$ of the total ciliate numbers and were abundant only in early summer in the hypoxic/anoxic $\left(\mathrm{O}_{2}<2 \mathrm{mg} \mathrm{l}^{-1}\right.$; Fig. 1B) part of the upper hypolimnion (ANOVA, $\mathrm{p}<0.01, \mathrm{n}=154$; Table 4, Fig. 3D). At that time the average cell number was $6.7 \mathrm{ml}^{-1}$ (range $0.43-14$ cells $\mathrm{ml}^{-1}$ ), and the population was made up almost entirely of a single hymenostomate species (Table 4). The correlation between APP and the omnivorous ciliates was negative in the hypolimnion $(r=-0.454, \mathrm{p}<0.05$; Table 3$)$, indicating that the omnivores were grazing on APP. The omnivores also correlated positively with algivorous ciliates in the hypolimnion $(r=0.716, \mathrm{p}<0.001$; Table 3), suggesting that they shared the same food resource.

The predatory ciliates were very low in number (on average 0.10 cells ml ${ }^{-1}$, range 0.0 to 1.5 cells ml$^{-1}$; Table 4 ) and made up only $1.0 \%$ of the total ciliate community. The predators showed a small maximum of 0.24 cells ml ${ }^{-1}$ in the epilimnion in July, but mainly they were present in autumn after the turnover with a maximum of 1.5 cells ml ${ }^{-1}$ near the bottom (Fig. 3E). Thus, they seemed to prefer cool and oxic waters (ANOVA, $\mathrm{p}<0.001, \mathrm{n}=154$ ). The seasonal dynamics was in contrast to that of the NFs, and the predators correlated negatively with the NFs $(r=-0.514, \mathrm{p}<$ 0.001; Table 3). However, in the late autumn mixing the numbers of NFs and predatory ciliates increased simultaneously (Fig. 3). The predatory ciliates correlated positively with bacterivorous ciliates and small bacteria $(r=0.583, \mathrm{p}<0.001$ and $r=0.588, \mathrm{p}<0.001$, respectively; Table 3 ) in the oxic water layers, which indicates that the predators were feeding on bacterivores.

The first 3 eigenvalues of the CCA for ciliates in the epilimnion and the hypolimnion explained approximately $90 \%$ of the variation in the data. The first eigenvalue, related to oxygen concentration and abundance of small bacteria, accounted for $42.9 \%$ $(p<0.01)$ of the overall variation. The second eigenvalue explained $25.0 \%(\mathrm{p}<0.01)$ of the variation and was related to chl $a$ and large bacteria (Fig. 4). The third eigenvalue for NF and chl a explained $21.9 \%$ $(p<0.01)$ of the variation (data not shown). The hypolimnetic samples in June formed a clear cluster of a distinct community under hypoxic/anoxic conditions $\left(\mathrm{O}_{2}<2 \mathrm{mg} \mathrm{l}^{-1}\right.$, Figs. 1B \& 4). The species in this cluster were the algivorous Prostomatida, the bac- 

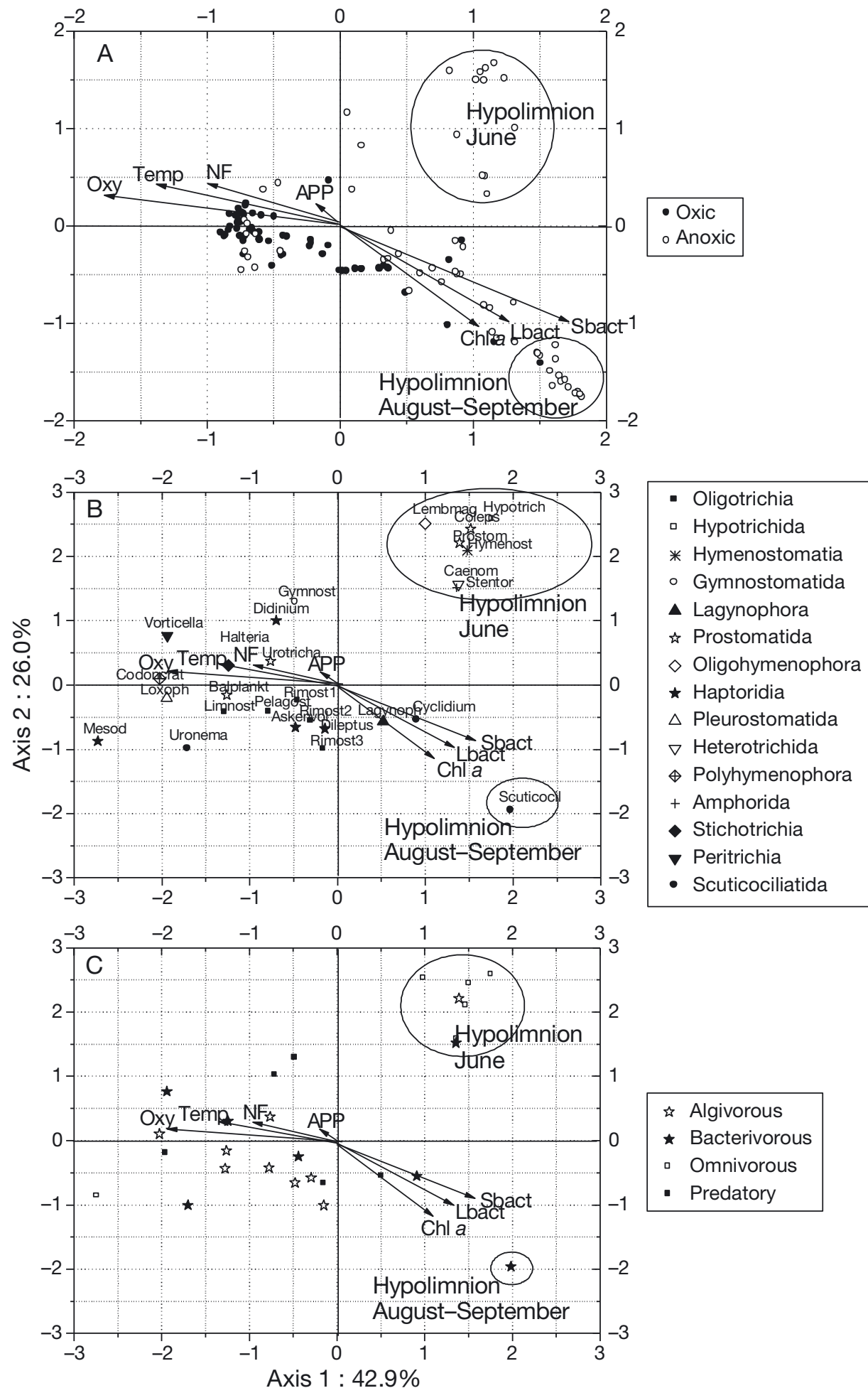

Fig. 4. Canonical correspondence analysis based on the abundance data showing the relationships between (A) environmental variables, (B) ciliate species composition and $(\mathrm{C})$ ciliate feeding preferences in Lake Valkea-Kotinen. Lengths of all arrows were multiplied by 3 for clarity. Eigenvalues of the axes are shown in the ordination. APP: autotrophic picoplankton; $\mathrm{Chl}$ a: chlorophyll a; Lbact: large bacteria; NF: heterotrophic nanoflagellates; Oxy: oxygen; Sbact: small bacteria; Temp: temperature. In panel B: Askenvol: Askenasia volvox; Balplank: Balanion planktonicum; Caenom: Caenomorpha sp.; Coleps: Coleps sp.; Cyclidium: Cyclidium sp.; Didinium: Didinium sp.; Dileptus: Dileptus sp.; Gymnost: Gymnostomatida; Halteria: Halteria sp.; Hymenost: Hymenostomata; Hypotrich: Hypotrichida; Lagynoph: Lagynophora sp.; Lembmag: Lembadion magnum; Limnost: Limnostrombidium sp.; Loxoph: Loxophyllum sp.; Mesod: Mesodinium sp.; Pelagost: Pelagotrombidium sp.; Prostom: Prostomatida; Rimost1: Rimostrom-

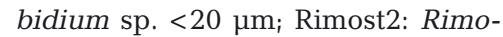
strombidium sp. 20-40 $\mu \mathrm{m}$; Rimost3: Rimostrombidium sp. $>40 \mu \mathrm{m}$ terivorous Caenomorpha sp. and the omnivores Lembadion magnum, Hymenostomata, Coleps sp., Hypotrichida and Stentor sp. (Fig. 4, Table 4). Another cluster, made up only of the bacterivorous scuticociliatid, was found in the anoxic hypolimnion in August-
September (Figs. 1B \& 4, Table 4). Except for these hypolimnetic groups, there were no clear signs of differentiation in ciliate community composition in relation to oxygen concentration, ciliate taxonomy or feeding preferences. 


\section{DISCUSSION}

Light plays a predominant role in controlling phytoplankton in humic brown-water lakes (Karlsson et al. 2009, Peltomaa \& Ojala 2010). Therefore, it was not surprising that the APP density in Lake Valkea-Kotinen was 2 orders of magnitude lower than in the clear-water Lake Vesijärvi (Bręk-Laitinen et al. 2012) and similar to that of eukaryotic APP in the humic Lake Vassiviere (Amblard et al. 1995). However, during the strongest stratification, most of the APP and chl $a$ in Lake Valkea-Kotinen was not found in the illuminated epilimnion but in the dark hypolimnion. This was already recorded by Peltomaa \& Ojala (2012) in their study of APP in Lake Valkea-Kotinen and can be explained by the attempts of autotrophic organisms to obtain both light, which is available only in the uppermost 2 to $3 \mathrm{~m}$ water layer, and nutrients, which are plentiful in the hypolimnion. In the epilimnion, the nonmotile APP must compete with larger phytoplankton and bacteria for inorganic nutrients, which was also indicated in the correlations between the APP and small bacteria. The bulk of the larger phytoplankton in Lake Valkea-Kotinen is flagellates, which are capable of retrieving nutrients from the hypolimnion (Peltomaa \& Ojala 2010), whereas via isopycny, the APP can remain close to the thermocline, i.e. at the interface between the illuminated and nutrient-rich layers (Peltomaa \& Ojala 2012).

While the lack of light and depletion of inorganic nutrients makes deeply stratified humic lakes harsh environments for photosynthetic organisms, the high amount of OM should favour heterotrophic bacteria (Jones 1992). We expected that bacteria would be abundant in Lake Valkea-Kotinen, but in fact their numbers were one order of magnitude lower than in the clearwater Lake Vesijärvi (Bręk-Laitinen et al. 2012). However, they were similar to those in the humic Lake Vassiviere (Amblard et al. 1995). The results on bacterial abundance were also in accordance with some previous findings on boreal humic lakes (Kuuppo-Leinikki \& Salonen 1992, Tulonen et al. 2000). We did not study viruses, and thus it is possible that the bacterial abundance was low due to the viral lytic activity, which is important for example in the humic Lake Vassiviere (Pradeep Ram et al. 2011). We expected the bacteria to be equally distributed in the water column rich in OM, but they were actually more abundant in the hypolimnion than in the epilimnion. In the epilimnion, bacteria are exposed to nutrient competition with phytoplankton, but simultaneously benefit from the extracellular organic compounds (EOC) excreted by phytoplankton (Kritzberg et al. 2005, Guenet et al. 2010). These compounds are more labile than allochthonous OM of terrestrial origin, which is poor in quality, since the easily degradable compounds are decomposed before the OM enters the lake (Lennon \& Pfaff 2005, Guenet et al. 2010). However, in Lake Valkea-Kotinen, most of the EOC production is related to Gonyostomum semen (Peltomaa \& Ojala 2010) that migrates diurnally between the epilimnion and the hypolimnion (Salonen \& Rosenberg 2000), and possibly provides EOC to bacteria in both layers. Thus, in Lake ValkeaKotinen, the results on bacteria in the epilimnion reflected the abundance of bacterivorous NFs. The importance of NFs as controllers of bacterial abundance in humic lakes has been shown previously (e.g. Kankaala et al. 1996).

In addition to small bacteria, we found a group of large prokaryotes residing in the anoxic hypolimnion. These were most likely either phototrophic and/or methanotrophic bacteria (Arvola 1984, Kankaala et al. 2006) or even Archaea (Jürgens et al. 2000). They were large enough to be oversized for NFs (Amblard et al. 1995), and thus could not be related to NFs in Lake Valkea-Kotinen, nor could they be associated with any feeding groups of ciliates. However, they could have been utilized by larger zooplankton, since Kankaala et al. (2010) showed in Lake Valkea-Kotinen that large methanotrophic bacteria contribute to crustacean zooplankton diets.

NFs were surprisingly abundant in Lake ValkeaKotinen, e.g. on average the densities were twice as high as in Lake Vesijärvi (Bręk-Laitinen et al. 2012) and 6 times higher than in Lake Vassiviere (Amblard et al. 1995). We expected that NFs would be associated with bacteria and possibly with APP, since they graze on bacteria as well as on phytoplankton (Sherr \& Sherr 2002, Bręk-Laitinen \& Ojala 2011). We found no correlation between the NFs and APP or larger phytoplankton, but the NFs presumably grazed on bacteria. The eukaryotic APP in Lake Valkea-Kotinen appeared fairly large in size, which could have affected the NF grazing efficiency (Amblard et al. 1995). Alternatively the NFs could have simply preferred the small bacteria, which clearly outnumbered the APP. As for the NFs, they outnumbered the bacterivorous ciliates by a factor of 100 to 1000 and thrived in the epilimnion, but were less abundant in the anoxic hypolimnion, where they faced competition with bacterivorous ciliates. The observations from the hypolimnion of Lake Valkea-Kotinen are in contrast with those recorded in the clearwater Lake Vesijärvi (Bręk-Laitinen et al. 2012). However, in all 
studies where the acriflavine staining method has been used the results may have been affected by the fact that acriflavine also stains the non-phagotrophic propaguoles of zoosporic organisms, which then resemble NFs under the microscope (Rasconi et al. 2011, Jobard et al. 2012).

The most common ciliates in Lake Valkea-Kotinen were the oligotrichs, prostomatids and scuticociliates, i.e. groups commonly found in lakes of various trophic states and over wide geographical areas (Hadas \& Berman 1998, Zingel 1999, Peštová et al. 2008, and references therein). The mean ciliate abundance was slightly higher than in Lake Vesijärvi (Bręk-Laitinen et al. 2012) and twice as high as in Lake Vassiviere (Amblard et al. 1995). We expected the ciliates to be selective feeders and follow both the dynamics of their particular food source as well as the dividing line of anoxia. As expected, the algivores in Lake Valkea-Kotinen were more abundant in the epilimnion and the omnivores in the hypolimnion. Furthermore, the predatory ciliates could be associated with the bacterivorous taxa and NFs after the autumn turnover. The only group of ciliates not associated with these assumed prey organisms was the bacterivores. This lack of association may have been due to selective feeding, i.e. these ciliates prefer active bacteria over dormant or dead ones, which however are often more abundant than metabolically active bacteria (del Giorgio et al. 1997; Tadonléké et al. 2005). As a result, bacterivorous scuticociliates tend to concentrate in water layers with the highest bacterial productivity, usually near the oxycline (Müller et al. 1991). In Lake Valkea-Kotinen, the scuticociliates were indeed the dominant bacterivores in the hypolimnion, whereas in the epilimnion the small-sized oligotrichs (Rimostrombidium sp. and Halteria sp.) were most numerous. Scuticociliates and oligotrichs can compete with each other (e.g. Zingel 2005), which also emphasizes their vertical niche separation.

As is typical of ciliate communities (Amblard et al. 1995, Zingel 1999, Peštová et al. 2008), the abundance of species in Lake Valkea-Kotinen varied with time and depth. However, regarding anoxia the results were somewhat surprising and most of the taxa observed were present in both oxic and anoxic waters, and only 5 taxa were found solely in the oxic and 2 in the anoxic layers. CCA showed that the only feeding group of ciliates clearly responding to environmental conditions was the omnivores in June, when the hypolimnion was not yet completely anoxic, but hypoxic. At that time, 5 of the 6 omnivores recorded in Lake Valkea-Kotinen were present.
Another cluster standing out in the CCA consisted of a single scuticociliatid species. This bacterivore was abundant in the anoxic hypolimnion in AugustSeptember. At lower temperatures, scuticociliates may be more effective grazers than small oligotrichs (Schönberger 1994), which could explain the dominance of scuticociliates in the deeper layers of Lake Valkea-Kotinen.

Except for the omnivores and scuticociliatids, no other feeding group or taxa responded to the oxygen concentrations or any other parameters included in the CCA. This is in contrast to the observations of Bręk-Laitinen et al. (2012), who found distinct ciliate communities in the epilimnion and hypolimnion of Lake Vesijärvi, and Guhl et al. (1996), who reported less diverse ciliate communities in the oxygendepleted hypolimnion of Priest Pot and Esthwaite Water in the English Lake District and Lake Arcas in Spain. These authors suggested that, in addition to oxygen, the clear diversity patterns stem from monotonous food sources in the anoxic waters. However, this was not the case in Lake Valkea-Kotinen, since the APP, larger phytoplankton and bacteria were regularly available both in the oxic epilimnion and the anoxic hypolimnion. Furthermore, the dividing line between the oxic epilimnion and the anoxic hypolimnion in Lake Valkea-Kotinen is diurnally disturbed through convective mixing (Nordbo et al. 2011), supplying the boundary layer with oxygen from the epilimnion above and nutrients from the hypolimnion below and nurturing the autotrophic and heterotrophic community around the thermocline. The amplitude of the mixing is highest during the strongest stratification, i.e. when the nutrient and oxygen limitation is most severe, and therefore extremely important for the organisms. The convective mixing is highly unpredictable, since it is driven by temperature differences, and thus ultimately by weather events. Hence, to study MFWs in lakes such as Valkea-Kotinen in more detail, we should employ continuous in situ measurements of both abiotic and biotic variables and extend them throughout the water column, since in shallow lakes the real nature of MFWs may be masked by temporary migrations of both prey and predators.

As a consequence of human activities, the habitats of MFWs in the boreal lakes are changing; e.g. temperature and DOC concentrations are increasing due to climate change and reduction in atmospheric sulphur deposition (IPCC 2007, Nickus et al. 2010). These changes will strengthen the thermal stratification, and thus eventually lead to hypolimnetic anoxia (Pérez-Fuentetaja et al. 1999). However, most of the 
boreal lakes are small and shallow (Downing et al. 2006), and our results from Lake Valkea-Kotinen indicate that in these lakes the existence of prey and predators in MFWs is not limited by strong thermal stratification and hypolimnetic anoxia. In fact, the predators were more abundant in Lake ValkeaKotinen than in the large, boreal clear-water Lake Vesijärvi (Bręk-Laitinen et al. 2012) or in the humic, nonstratifying French Lake Vassiviere (Amblard et al. 1995). In contrast, the prey numbers were considerably lower in Lake Valkea-Kotinen than in the other 2 lakes, which is not surprising since grazing pressure was probably high in Lake Valkea-Kotinen. The increase in DOC concentration may not enhance bacterial growth in phosphorus-limited lakes (Smith \& Prairie 2004), but it instead leads to stronger thermal stratification and decreased light penetration, both of which favour eukaryotic APP (Peltomaa \& Ojala 2012). When APP become more abundant, the algivorous and omnivorous ciliates probably increase in numbers too. This is then reflected further up in the aquatic food web (Gilbert \& Jack 1993, Jürgens et al. 1999, Kalinowska 2004).

Acknowledgements. This research was funded by the Helsinki University Research Centre (HERC; project REBECCA). Lammi Biological Station (University of Helsinki) provided the working facilities and the International Cooperative Programme on Integrated Monitoring of Air Pollution Effects on Ecosystems data. The authors thank Mirka Autio, Riitta Ilola and Jaakko Vainionpää (Lammi Biological Station) for their contribution in sampling and laboratory analyses, and James Thompson for revising the English of the manuscript. We also thank Jouni Heiskanen for his help with the isopleths.

\section{LITERATURE CITED}

Agasild H, Zingel P, Tõnno I, Haberman J, Nõges T (2007) Contribution of different zooplankton groups in grazing on phytoplankton in shallow eutrophic Lake Võrtsjärv (Estonia). Hydrobiologia 584:167-177

> Amblard C, Carrias JF, Bourdier G, Maurin N (1995) The microbial loop in a humic lake: seasonal and vertical variations in the structure of the different communities. Hydrobiologia 300-301:71-84

> Arndt H (1993) Rotifers as predators on components of the microbial web (bacteria, heterotrophic flagellates, ciliates) - a review. Hydrobiologia 255-256:231-246

Arvola L (1984) Vertical distribution of primary production and phytoplankton in two small lakes with different humus concentration in southern Finland. Holarct Ecol 7: 390-398

> Azam F, Fenchel T, Field JG, Gray JS, Meyer-Reil LA, Thingstad F (1983) The ecological role of water-column microbes in the sea. Mar Ecol Prog Ser 10:257-263

Bergström I, Heinänen A, Salonen K (1986) Comparison of acridine orange, acriflavine, and bisbenzimide stains for enumeration of bacteria in clear and humic waters. Appl Environ Microbiol 51:664-667

Bręk-Laitinen G, Ojala A (2011) Grazing of heterotrophic nanoflagellates on the eukaryotic photoautotroph Choricystis sp. Aquat Microb Ecol 62:49-59

> Bręk-Laitinen G, López Bellido J, Ojala A (2012) Response of a microbial food web to prolonged seasonal hypoxia in a boreal lake. Aquat Biol 14:105-120

> Colombet J, Sime-Ngando T (2012) Seasonal depth-related gradients in virioplankton: lytic activity and comparison with protistan grazing potential in Lake Pavin (France). Microb Ecol 64:67-78

> Daniel C, Gutseit K, Anesio AM, Granéli W (2005) Microbial food webs in the dark: independence of lake plankton from recent algal production. Aquat Microb Ecol 38: 113-123

del Giorgio PA, Prairie YT, Bird DF (1997) Coupling between rates of bacterial production and the abundance of metabolically active bacteria in lakes, enumerated using CTC reduction and flow cytometry. Microb Ecol 34:144-154

D'Elia CF, Steudler PA, Corwin N (1977) Determination of total nitrogen in aqueous samples using persulfate digestion. Limnol Oceanogr 22:760-764

Downing JA, Prairie YT, Cole JJ, Duarte CM and others (2006) The global abundance and size distribution of lakes, ponds, and impoundments. Limnol Oceanogr 51: 2388-2397

> Eby LA, Crowder LB, McClellan CM, Peterson CH, Powers MJ (2005) Habitat degradation from intermittent hypoxia: impacts on demersal fishes. Mar Ecol Prog Ser 291:249-262

Foissner W, Berger H (1996) A user-friendly guide to the ciliates (Protozoa, Ciliophora) commonly used by hydrobiologists as bioindicators in rivers, lakes, and waste waters, with notes on their ecology. Freshw Biol 35: 375-482

Foissner W, Blatterer H, Berger H, Kohmann F (1991) Taxonomische und ökologische Revision der Ciliaten des Saprobiensystems - Band I: Cyrtophorida, Oligotrichida, Hypotrichia, Colpodea. Informationsberichte des Bayerisches Landesamtes für Wasserwirtschaft 1/91. Bayerisches Landesamtes für Wasserwirtschaft, Deggendorf

Foissner W, Berger H, Kohmann F (1992) Taxonomische und ökologische Revision der Ciliaten des Saprobiensystems — Band II: Peritrichia, Heterotrichida, Odontostomatida. Informationsberichte des Bayerisches Landesamtes für Wasserwirtschaft 5/92. Bayerisches Landesamt für Wasserwirtschaft, Deggendorf

Foissner W, Berger H, Kohmann F (1994) Taxonomische und ökologische Revision der Ciliaten des Saprobiensystems —Band III: Hymenostomata, Prostomatida, Nassulida. Informationsberichte des Bayerisches Landesamtes für Wasserwirtschaft 1/94. Bayerisches Landesamt für Wasserwirtschaft, Deggendorf

Foissner W, Berger H, Blatterer H, Kohmann F (1995) Taxonomische und ökologische Revision der Ciliaten des Saprobiensystems - Band IV: Gymnostomatea, Loxodes, Suctoria. Informationsberichte des Bayerisches Landesamtes für Wasserwirtschaft 1/95. Bayerisches Landesamt für Wasserwirtschaft, Deggendorf

Foissner W, Berger H, Schaumburg J (1999) Identification and ecology of limnetic plankton ciliates. Informationsberichte des Bayerisches Landesamtes für Wasser- 
wirtschaft 3/99. Bayerisches Landesamt für Wasserwirtschaft, Deggendorf

Gilbert JJ, Jack JD (1993) Rotifers as predators on small ciliates. Hydrobiologia 255-256:247-253

- Gobler CJ, Davis TW, Deonarine SN, Saxton MA, Lavrentyev PJ, Jochem FJ, Wilhelm SW (2008) Grazing and virus-induced mortality of microbial populations before and during the onset of annual hypoxia in Lake Erie. Aquat Microb Ecol 51:117-128

Grasshoff K (1983) Determination of nitrate. In: Grasshoff K, Ehrhardt M, Kremling K (eds) Methods of seawater analysis. Verlag Chemie, Weinheim, p 143-150

Guenet B, Danger M, Abbadie L, Lacroix G (2010) Priming effect: bridging the gap between terrestrial and aquatic ecology. Ecology 91:2850-2861

Guhl BE, Findlay BJ, Schink B (1996) Comparison of ciliate communities in the anoxic hypolimnia of three lakes: general features and the influence of lake characteristics. J Plankton Res 18:335-353

$>$ Hadas O, Berman T (1998) Seasonal abundance and vertical distribution of Protozoa (flagellates, ciliates) and bacteria in Lake Kinneret, Israel. Aquat Microb Ecol 14:161-170

Hammer Ø, Harper DAT, Ryan PD (2001) PAST: Paleontological Statistics Software Package for Education and Data Analysis. Palaeontol Electronica 4:1-9

Huotari J, Ojala A, Peltomaa E, Pumpanen J, Hari P, Vesala $\mathrm{T}$ (2009) Temporal variations in surface water $\mathrm{CO}_{2}$ concentration in a boreal humic lake based on highfrequency measurements. Boreal Environ Res 14(Suppl A):48-60

IPCC (Intergovernmental Panel on Climate Change) (2007) The physical science basis. In: Solomon S, Qin D, Manning M, Chen Z and others (eds) Climate change 2007. Contribution of Working Group I to the Fourth Assessment Report of the Intergovernmental Panel on Climate Change. Cambridge University Press, Cambridge

> Jobard M, Rasconi S, Solinhac L, Cauchie MH, SimeNgando T (2012) Molecular and morphological diversity of fungi and the associated functions in three European nearby lakes. Environ Microbiol 14:2480-2494

- Jones RI (1992) The influence of humic substances on lacustrine planktonic food chains. Hydrobiologia 229:73-91

> Jürgens G, Skibbe O, Jeppesen E (1999) Impact of metazooplankton on the composition and population dynamics of planktonic ciliates in a shallow, hypertrophic lake. Aquat Microb Ecol 17:61-75

Jürgens G, Glöckner FO, Amann R, Saano A, Montonen L, Likolammi M, Münster U (2000) Identification of novel Archaea in bacterioplankton of a boreal forest lake by phylogenetic analysis and fluorescent in situ hybridization. FEMS Microbiol Ecol 34:45-56

Kahl A (1930) Urtiere oder Protozoa I: Wimpertiere oder Ciliata (Infusoria) 1. Allgemeiner Teil und Prostomata. Tierwelt Deutschlands 18:1-180

Kahl A (1931) Urtiere oder Protozoa I: Wimpertiere oder Ciliata (Infusoria) 2. Holotricha außer den im 1. Teil behandelten Prostomata. Tierwelt Deutschlands 21: 181-398

Kahl A (1932) Urtiere oder Protozoa I: Wimpertiere oder Ciliata (Infusoria) 3. Spirotricha. Tierwelt Deutschlands 25:399-650

Kahl A (1935) Urtiere oder Protozoa I: Wimpertiere oder Ciliata (Infusoria) 4. Peritricha und Chonotricha. Tierwelt Deutschlands 30:651-886

Kalinowska K (2004) Bacteria, nanoflagellates and ciliates as components of the microbial loop in three lakes of different trophic status. Pol J Ecol 52:19-34

Kankaala P, Arvola L, Tulonen T, Ojala A (1996) Carbon budget for the pelagic food web of the euphotic zone in a boreal lake. Can J Fish Aquat Sci 53:1663-1674

Kankaala P, Huotari J, Peltomaa E, Saloranta T, Ojala A (2006) Methanotrophic activity in relation to methane efflux and total heterotrophic bacterial production in a stratified, humic, boreal lake. Limnol Oceanogr 51: 1195-1204

Kankaala P, Taipale S, Li L, Jones RI (2010) Diets of crustacean zooplankton, inferred from stable carbon and nitrogen isotope analyses, in lakes with varying allochthonous dissolved organic carbon content. Aquat Ecol 44:781-795

Karlsson J, Byström P, Ask J, Ask P, Persson L, Jansson M (2009) Light limitation of nutrient-poor lake ecosystem. Nature 460:506-509

Keskitalo J, Salonen K (1994) Manual for integrated monitoring. Subprogram Hydrobiology of Lakes. Publications of the Water and Environment Administration - series B 16. National Board of Waters and the Environment, Helsinki, Finland

Keskitalo J, Salonen K, Holopainen AL (1998) Long-term fluctuations in environmental conditions, plankton and macrophytes in a humic lake, Valkea-Kotinen. Boreal Environ Res 3:251-262

> Kisand V, Zingel P (2000) Dominance of ciliate grazing on bacteria during spring in a shallow eutrophic lake. Aquat Microb Ecol 22:135-142

Koroleff F (1983) Determination of phosphorus. In: Grasshoff K, Ehrhardt M, Kremling K (eds) Methods of seawater analysis. Verlag Chemie, Weinheim, p 125-136

Kritzberg ES, Cole JJ, Pace MM, Granéli W (2005) Does autochthonous primary production drive variability in bacterial metabolism and growth efficiency in lakes dominated by terrestrial C inputs? Aquat Microb Ecol 38: 103-111

Kuuppo-Leinikki P, Salonen K (1992) Bacterioplankton in a small polyhumic lake with an anoxic hypolimnion. Hydrobiologia 229:159-168

> Lennon JT, Pfaff LE (2005) Source and supply of terrestrial organic matter affects aquatic microbial metabolism. Aquat Microb Ecol 39:107-119

Lepistö L, Rosenström U (1998) The most typical phytoplankton taxa in four types of boreal lakes. Hydrobiologia 369/370:89-97

Lund JW, Kipling C, LeCren ED (1958) The inverted microscope method of estimating algal numbers and the statistical basis of estimations by counting. Hydrobiologia 11: 143-170

Massana R, García-Cantizano J, Pedrós-Alió C (1996) Components, structure and fluxes of the microbial food web in a small, stratified lake. Aquat Microb Ecol 11:279-288

- Masson S, Pinel-Alloul B (1998) Spatial distribution of zooplankton biomass size fractions in a bog lake: abiotic and (or) biotic regulation? Can J Zool 76:805-823

Mischke U (1994) Influence of food quality and quantity on ingestion and growth rates of three omnivorous heterotrophic flagellates. Mar Microb Food Webs 8:125-143

> Müller H, Schöne A, Pinto-Coelho RM, Schweizer A, Weisse $\mathrm{T}$ (1991) Seasonal succession of ciliates in Lake Constance. Microb Ecol 21:119-138

Nickus U, Bishop K, Elandsson M, Evans CD and others (2010) Direct impacts of climate change on freshwater 
ecosystems. In: Kernan M, Battarbee RW, Moss B (eds) Climate change impacts on fresheater ecosystems. Wiley-Blackwell, Chichester, p 38-64

Niinioja R, Villa L, Ylitolonen A, Mähönen O (1995) Material and methods. Water chemistry. In: Bergström I, Mäkelä K, Starr M (eds) Integrated Monitoring Programme in Finland. First National Report. Ministry of Environment, Environmental Policy Department, Helsinki, p 78-83

Nordbo A, Launiainen S, Mammarella I, Leppäranta M, Huotari J, Ojala A, Vesala T (2011) Long-term energy flux measurements and energy balance over a small boreal lake using eddy covariance technique. J Geophys Res 116:D02119, doi: 10.1029/2010JD014542

Peltomaa E, Ojala A (2010) Size-related photosynthesis of algae in a strongly stratified humic lake. J Plankton Res 32:341-355

Peltomaa E, Ojala A (2012) Climatic drivers behind the dynamics of autotrophic picoplankton. Freshw Biol 57: 1005-1016

Pérez-Fuentetaja A, Dillon PJ, Yand ND, McQueen DJ (1999) Significance of dissolved organic carbon in the prediction of thermocline depth in small Canadian shield lakes. Aquat Ecol 33:127-133

Peštová D, Macek M, Martinez Peres ME (2008) Ciliates and their picophytoplankton-feeding activity in a highaltitude warm-monomictic saline lake. Eur J Protistol 44: 13-25

Pradeep Ram AS, Rasconi S, Jobard M, Palesse S, Colombet J, Sime-Ngando T (2011) High lytic infection rates but low abundances of prokaryote viruses in a humic lake (Vassiviere, Massif Central, France). Appl Environ Microbiol 77:5610-5618

Rasconi S, Sime-Ngando T (2012) Phytoplankton chytridiomycosis: community structure and infectivity of fungal parasites in aquatic ecosystems. Environ Microbiol 14: 2151-2170

Rasconi S, Jobard M, Sime-Ngando T (2011) Parasitic fungi of phytoplankton: ecological roles and implications for microbial food webs. Aquat Microb Ecol 62:123-137

Salonen K (1981) Rapid and precise determination of total inorganic carbon and some gases in aqueous solutions. Water Res 15:403-406

Salonen K, Rosenberg M (2000) Advantages from diel vertical migration can explain the dominance of Gonyostomum semen (Raphidophyceae) in a small, steeply stratified humic lake. J Plankton Res 22:1841-1853

Sanders RW, Porter KG, Bennet SJ, Biase AE (1989) Sea-

Editorial responsibility: Urania Christaki, Wimereux, France sonal patterns of bacterivory by flagellates, ciliates, rotifers, and cladocerans in a freshwater planktonic community. Limnol Oceanogr 34:673-687

Schönberger M (1994) Planktonic ciliated protozoa of Neusiedler See (Austria/Hungary) - a comparison between the turbid open lake and a reedless brown-water pond. Mar Microb Food Webs 8:251-263

Sherr EB, Sherr BF (2002) Significance of predation by protists in aquatic microbial food webs. Antonie van Leeuwenhoek 81:293-308

Šimek K, Hartman P, Nedoma J, Pernthaler J, Springmann D, Vrba J, Psenner R (1997) Community structure, picoplankton grazing and zooplankton control of heterotrophic nanoflagellates in a eutrophic reservoir during the summer phytoplankton maximum. Aquat Microb Ecol 12:49-63

Smith EK, Prairie YT (2004) Bacterial metabolism and growth efficiency in lakes: the importance of phosphorus availability. Limnol Oceanogr 49:137-147

Tadonléké RD, Planas D, Lucotte M (2005) Microbial food webs in boreal humic lakes and reservoirs: ciliates as a major factor related to the dynamics of the most active bacteria. Microb Ecol 49:325-341

Tulonen T, Kankaala P, Arvola L, Ojala A (2000) Growth and production of bacterioplankton in a deep mesohumic boreal lake. Arch Hydrobiol 147:311-325

Utermöhl H (1958) Zur Vervollkommnung der quantitativen Phytoplankton-Methodik. Mitt Int Verein Theor Angew Limnol 9:1-38

> Verni F, Gualtieri P (1997) Feeding behaviour in ciliated protists. Micron 28:487-504

- Wintermans JFGM, De Mots A (1965) Spectrophotometric characteristics of chlorophyll $a$ and $b$ and their phaeophytins in ethanol. Biochim Biophys Acta 109:448-453

Zingel P (1999) Pelagic ciliated protozoa in a shallow eutrophic lake: community structure and seasonal dynamics. Arch Hydrobiol 146:495-511

Zingel P (2005) Vertical and seasonal dynamics of planktonic ciliates in a strongly stratified hypertrophic lake. Hydrobiologia 547:163-174

Zingel P, Nõges T (2008) Protozoan grazing in shallow macrophyte- and plankton lakes. Fundam Appl Limnol. Arch Hydrobiol 171:15-25

Zingel P, Agasild H, Nõges T, Kisand V (2007) Ciliates are the dominant grazers on pico- and nanoplankton in a shallow, naturally highly eutrophic lake. Microb Ecol 53: 134-142

Submitted: June 20, 2012; Accepted: October 9, 2012 Proofs received from author(s): December 12, 2012 